Special Issue 特集論文

Invited Peer-Reviewed Article 招待査読論文

\title{
The Effects of Goal Conflict in Consumer Sequential Choices 消費者の逐次選択における目標コンフリクトの影響 一 各選択の関連性に着目した分析 一
}

\author{
Naoki Akamatsu*1, Reo Fukuda*2 \\ 明治学院大学 経済学部 \\ 赤松 直樹 \\ 亜細亜大学 経営学部 \\ 福田 怜生

\footnotetext{
${ }^{*}$ Faculty of Economics, Meiji Gakuin University, Japan, akamatsu@eco.meijigakuin.ac.jp

${ }^{* 2}$ Faculty of Business Administration, Asia University, Japan, rfkd@asia-u.ac.jp
}

\begin{abstract}
The current research focuses on the relevance of each choice as a factor that moderates the influence of prior choices on subsequent choices, and discusses the interaction between this relevance and a consumer characteristic, health awareness.
\end{abstract}

Keyword : Sequential choice, Goal conflict, Health

要約 : 本研究では, ある選択がその後の選択に及ぼす影響の調整要因について議論した。逐次選択は, 複数の選択間における選 択行動であるが, 既存研究では調整要因として消費者特性などが主に議論されており, 各選択の関係については十分な議論がな されてこなかった。そのため, 本研究は調整要因として各選択の関連性に着目し, 消費者特性である健康意識との交互作用を考 慮しながらその働きについて分析した。その結果, 健康意識が高い消費者は, 健康状態の維持に関する目標と美味しいものを食 すことで快楽を得るといつた目標の間でコンフリクト状態にあることが想定でき, 事前選択でどちらか一方の目標を進展させる と, その後の選択では進展がなされていないもう一方の目標に対応した選択を行う傾向が示された。そして, この傾向は各選択 の関連性が高い場合に生じる点も確認された。これらは逐次選択の影響が生じる条件に関する新たな知見であると言える。

キーワード : 逐次選択, 目標コンフリクト, 健康

Information : Received 27 May 2020; Accepted 3 June 2020

\section{I. はじめに}

消費者は，複数の選択を逐次的に行うことがよくある。 例えば，食品スーパーでの買物場面を思い浮かべてみる と，消費者は店内を歩きながら，複数の異なる製品カテ ゴリーについて逐次的に選択を行っている。またレス トランなどの飲食店においても，異なる料理や飲物につ いて逐次的に選択を行うことは珍しいことではない。つ まり，異なる選択を逐次的に行うこと（逐次選択）は, 日常的に行われる消費者行動の一つである。

逐次選択に関する既存研究では，事前の選択がその後 の選択に及ぼす影響（逐次選択の影響）が確認されてお り（Dhar \& Simonson, 1999），ある一つの選択に焦点を
絞った議論だけではなく, 逐次的に行われる複数の選択 をまとめて議論することは重要であると言える。そのた め, 今日においては, 逐次選択に関する研究は活発に行 われており (e.g., Dholakia, Gopinath, \& Bagozzi, 2005; Mukhopadhyay \& Johar, 2009), 逐次選択の影響が生じる メカニズムや調整要因の解明などが進められている。

本研究は, 逐次選択研究に位置づけられ, その中でも, 逐次選択の影響の新たな調整要因の提示を目的とする。 具体的には, 事前選択とその後の選択の関連性に着目し, 関連性が高い場合と低い場合では, 逐次選択の影響が異 なる点について検討する。

その際には, 消費者特性の一つとして健康意識につい ても議論し, 逐次選択の影響における各選択の関連性と 健康意識の交互作用を明らかにする。逐次選択の研究で 
は，食品選択を想定した実験・調査が多く行われている にも関わらず，食品選択と深く関わっている健康意識 (Chandon \& Wansink, 2007; Moorman \& Matulich, 1993) に着目した分析は十分ではない。そのため, 本研究では, 既存研究で示された逐次選択の影響を健康意識が調整す る点を明らかにする。

\section{II. 既存研究}

\section{1. 逐次選択の影響}

逐次選択の影響とは，ある選択がその後の選択に及ほ す影響のことであり（Dholakia et al., 2005），この影響の メカニズムや調整要因について活発に研究が行われてい る。その際，消費者の目標に着目した議論が主に行われ ており（Sunaga, 2013），特に，複数のコンフリクトする 目標の存在を前提とした研究が多く，その先駆的な研究 の一つとして Dhar and Simonson（1999）がある。

彼らの研究では, 複数のコンフリクトする目標として, 快楽の追求と資源の維持・節約の 2 つに着目し，逐次的

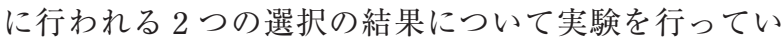
る。その結果，各選択において提示される選択肢の類似 性が高い場合には（食前の「夕バコ」と食後の「タバ コ」)，各選択はそれぞれに異なる目標に従う傾向があり (食前の夕バコは高（低）価格, 食後の夕バコは低（高） 価格)，類似性が低い場合には（観戦「座席」と観戦中に 飲む「ビール」)，各選択はどちらか一方だけの目標に従 う傾向（高（低）価格な座席, 高（低）価格なビール） を示している。

彼らの研究の貢献は, 逐次選択の影響を示した点, 選 択肢の類似性の高低によってその影響が異なることを示 した点, そして，複数のコンフリクトする目標の存在を 考慮しながら逐次選択の心理メカニズムについて議論し た点である。

Fishbach and Dhar（2005）では，事前選択とその後の 選択の 2 つの選択を想定した場合，事前選択における目 標の進展程度に対する知覚によって，その後の選択の結 果が異なる点を示している。具体的には，事前選択にお いて，ある目標が十分に進展したと知覚した場合には，
その後の選択では, 当該目標とは異なる目標に従う選択 を行い (バランス傾向), 一方で, ある目標の進展が十分 でないと知覚した場合には, その後の選択においても当 該目標に従った選択が行われる点（強化傾向）が指摘さ れている (Huber, Goldsmith, \& Mogilner, 2008)。その後, 多くの研究において彼女らが示した心理メカニズムと整 合する分析結果が報告されている（e.g., May \& Irmak, 2014)。

逐次選択に関する研究においてコンフリクトする目標 の内容は, 基本的には, 自己制御に関する目標とそれに 反する目標が想定されている。例えば，自己制御に関す る目標として, 体重維持 (e.g., Fishbach \& Dhar, 2005; Lee, Weaver, \& Garcia, 2016), 健康維持・向上（e.g., Akamatsu \& Fukuda, 2018; Finkelstein \& Fishbach, 2013; Laran, 2010a), 資源維持 (e.g., Dhar \& Simonson, 1999), 衝動購 買や消費の抑制（e.g., Mukhopadhyay \& Johar, 2009）など が挙げられる。一方, 自己制御に関する目標とコンフリ クトする目標とは, 自己制御をせずに生じる行動によっ て得られる状態のことであり, その多くは, 快楽的な商 品や高価格な商品を選択, 消費することで得られる状態 などが想定されている。

\section{2. 逐次選択の影響の調整要因と本研究の課題}

逐次選択の影響の調整要因に関する分析には，消費者 特性や選択時における消費者の意識に着目した分析が主 に行われている。

消費者特性, 例えば, 体重維持に対する意識に着目し た研究では, 体重維持の意識が高い消費者の方が, 低い 消費者よりも，逐次的な 2 つの選択において自己制御に 対応した選択肢（健康的な食品）と自己制御に反する選 択肢（快楽的な食品）をバランスよく選択する傾向が確 認されている（Lee et al., 2016）。この結果は, 体重維持 に対する意識が高い消費者の場合には，自己制御に関す る目標とそうでない目標との間にコンフリクトが生じた ため, 一方の目標に従う選択を行った後, もう一方の目 標に従う選択を行っている点を裏付けるものである。こ のことから, 体重維持の意識といった消費者特性が, 逐 次選択の影響を調整している点が理解できる (Finkelstein \& Fishbach, 2013)。 
衝動性の高低に着目した Mukhopadhyay, Sengupta, and Ramanathan（2008）では，衝動性が高い消費者は，以前 の選択で衝動購買を行った経験よりも，それを抑制した 経験を思い出すことで, 現在の選択に打いて衝動購買が 促進される点を確認している。さらに，衝動購買につい ては，一般的な事柄に対する感度の違いによっても，逐 次選択の影響が調整されている点が確認されている (Dholakia et al., 2005)。具体的には，日常生活における 自身の行動の結果に関して，良い結果に対する感度がよ り高い消費者と, 悪い結果に対する感度がより高い消費 者では，後者の方が，事前選択において衝動購買が生じ た場合には，その後の選択では衝動購買をより抑制する ことが示されている。

実験手続きやシナリオによって，選択時における消費 者の意識を操作することで, 逐次選択の影響の違いを確 かめている研究もある。例えば，アンケート調査におい て逐次的な 2 つ選択課題を与える際, 目標の階層性を 考慮し，より抽象的な目標を意識させた場合とそうでな い場合では，前者の方が後者よりも，事前選択とその後 の選択の両方において同一の抽象的な目標に従った選択 を行う傾向が確認されている（Fishbach, Dhar, \& Zhang, 2006)。また，事前選択の結果を顕在化させた場合とそ うでない場合では，その後の選択の結果が異なる点が確 認されている (Mukhopadhyay \& Johar, 2009)。

その他にも, 近い将来の選択なのか遠い将来の選択な のかといった時間的距離に着目した分析 (Laran, 2010a), 自分自身に対する選択なのか他者に対する選択なのかと いった消費・使用する人に着目した分析（Laran, 2010b) も行われている。

このように，消費者特性や選択時の消費者意識に着目 した分析が主に行われていることがわかる。一方で，逐 次選択は，事前選択とその後の選択といった複数の選択 間における消費者行動であるにも関わらず，各選択の関 係については十分な議論がなされていない。その中でも， Dhar and Simonson（1999）では，前項で記述した通り， 各選択の関係について，消費場面（消費エピソード）が 同じ場合を主に想定した上で，選択肢の類似性の程度に よって逐次選択の影響が異なる点を確認している。

この点とは別に, 我々の研究では, 選択間の関係を捉
える視点として各選択の関連性に言及する。その理由は, 選択肢の類似性の程度が同じ場合でも，各選択の関連性 が高い場合（例：観戦「座席」と観戦中に飲む「ビール」） の方が，低い場合（例：観戦「座席」と帰宅後に飲む 「ビール」）よりも，各選択に関わりがある分だけ事前選 択の結果をより考虑しながらその後の選択が行われる傾 向があると考えられるためである。つまり，選択肢の類 似性の程度が同じ場合でも, 各選択の関連性の程度が異 なれば，逐次選択の影響も異なると考えられる。

以上のことから, 本研究では, 事前選択とその後の選 択の関連性に着目し, 既存研究で確認されてきた逐次選 択の影響が，関連性の高低によって調整される点を明ら かにする。これにより，逐次選択の影響が生じる新たな 条件を特定することができるだろう。

また, 各選択の関連性に加え, 本研究では, 逐次選択 の影響の調整要因として消費者特性の一つである健康意 識についても検討する。逐次選択研究では, 食品選択を 想定した研究が多くなされているにも関わらず，その選 択と深く関わっている健康意識（Chandon \& Wansink, 2007; Moorman \& Matulich, 1993）について十分に議論で きていない。そのため, 本研究では, 既存研究で示され ている逐次選択の影響が，健康意識によって調整される 点を明らかにする。

\section{III. 仮説設定}

ここでは, 食品選択場面を想定した上で逐次選択の影 響の調整要因として，消費者特性である健康意識 $(\mathrm{H} 1)$, 事前選択とその後の選択の関連性（H2）に着目して仮説 を設定する。

\section{1. 消費者特性の検討：健康意識}

健康状態の維持や向上に関して高い関心を持つ消費 者, すなわち, 健康意識が高い消費者は, そうでない消 費者よりも, 食品の選択場面に押いてカロリーや添加物 といった健康に関わる項目に着目する点が示されている (Moorman \& Matulich, 1993)。この場合, 彼らは健康状 態の維持や向上といった健康に関する目標（以下，健康 
目標）を活性化させていると考えられる。

また，彼らは健康目標といった自己制御に関する目標 だけを活性化させているわけではなく，消費者は基本的 には快楽的な消費にヨリ動機づけられることが想定でき るため (Okada, 2005)，逐次選択に関する既存研究でも 指摘されているように，彼らは自己制御に関する目標と コンフリクトする目標を同時に有していると考えられる (e.g., Fishbach \& Dhar, 2005; Laran \& Janiszewski, 2009)。 そのため, 本研究では, 健康目標とコンフリクトする目 標として健康状態の維持や向上に寄与しない美味しさを 追求した選択肢によって達成できる目標（以下，快楽目 標）を想定する。そして, 健康目標に対応する選択肢と して低カロリーや低糖質の選択肢（以下，健康型製品）, 快楽目標に対応する選択肢として低カロリーや低糖質で はないがより美味しい選択肢（以下, 快楽型製品）を設 定する。

健康意識が高い消費者, つまり, 健康目標と快楽目標 の間でコンフリクト状態にある場合, 事前選択として健 康型製品を選択した場合には, 健康目標が進展するため, その後の選択では, コンフリクトしているもう一方の目 標（快楽目標）に対応した快楽型製品を選択することが 推測できる（Fishbach \& Dhar, 2005）。ここで重要な点 は, 健康意識が高い消費者であっても, 事前選択におい て健康目標が進展する場合には, その後の選択では快楽 目標に従った選択を行う傾向が推測できる点であり（Lee et al., 2016)，このことから, 逐次的に行われる複数の選 択を包括的に議論することの意義を指摘することができ る。一方, 事前選択として快楽型製品を選択した場合に は, この時点では彼らの健康目標は進展していないので, その後の選択では健康型製品を選択すると考元られる (Finkelstein \& Fishbach, 2013)。

以上のことから, 健康意識が高い消費者は, 健康目標 と快楽目標の間でコンフリクト状態にあるため, 事前選 択においてどちらか一方の目標に従う選択を行った場合, もう一方の目標はまだ進展がなされていないので, その 後の選択では, もう一方の目標に従う選択を行うことが 推測できる。即ち,

$\mathrm{H} 1$ 複数の目標間でコンフリクト状態にある場合, 事前
選択において特定の目標に従う選択が行われた場合 には, その後の選択では, 進展がなされていないも う一方の目標に従う選択を行う

が設定できる。

他方, 健康意識が低い消費者は, 健康目標に対する動 機づけが弱く, 健康目標と快楽目標の間でコンフリクト 状態にあるとは考えにくい。つまり, 食品選択場面では この 2 つの目標のうち快楽目標のみが活性化しているた め, 事前選択において快楽型製品を選択した場合でも, その後の選択においても快楽型製品を選択することが推 測できる。一方, マーケティング刺激などによって, 事 前選択において健康型製品を選択した場合には, 快楽目 標が進展していないため, その後の選択では快楽型製品 を選択する傾向があると考えられる（Fishbach \& Dhar, 2005)。つまり, 健康意識が低く, 健康目標と快楽目標 の間でコンフリクト状態にない消費者の場合は, 事前選 択の結果によってその後の選択の結果に差は生じないと 考えられる。

\section{2. 各選択の関連性の検討 : 消費場面の同異}

逐次選択の影響の調整要因として各選択の関連性に着 目し，健康意識との交互作用を考虑しながら，その働き について検討する。その際, 各選択の関連性については, 各選択の消費場面に着目して捉えることとする（図 1)。 具体的には, 消費場面が同じ場合には関連性は高く(例： 事前選択とその後の選択, 共に「晚御飯」), 異なる場合 には関連性が低いと判断する(例 : 事前選択は「晚御飯」, その後の選択は「夜食」)。消費者の選択の結果やそのプ ロセスは，選択する製品やサービスの消費・使用場面， 状況によって影響を受ける点が確認されているため (Ratneshwar, Pechmann, \& Shocker, 1996; Srivastava, Alpert, \& Shocker, 1984), 消費場面の同異によって, 各 選択の関連性の程度は異なると考えられる。尚, ここで 設定する仮説は, 議論を単純化するため, 事前選択とし て快楽型製品を想定する。

事前選択とその後の選択の消費場面が同じ場合（関連 性が高い場合）は, 消費場面が異なる場合よりも, 事前 選択の結果をより考慮しながらその後の選択を行うと考 


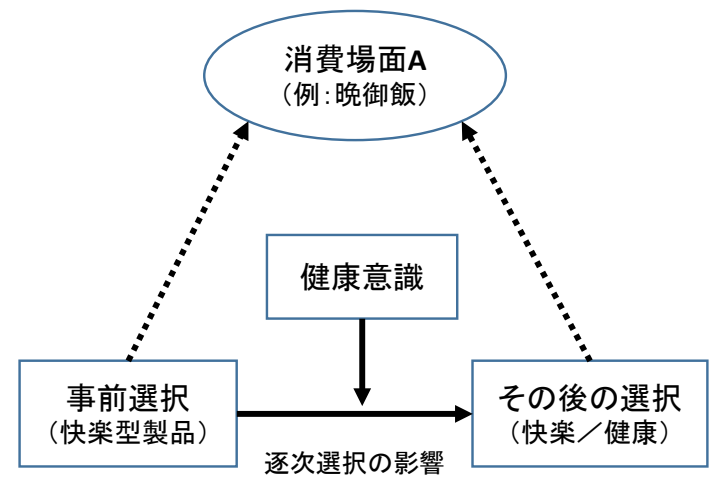

各選択の関連性(高): 消費場面が同じ

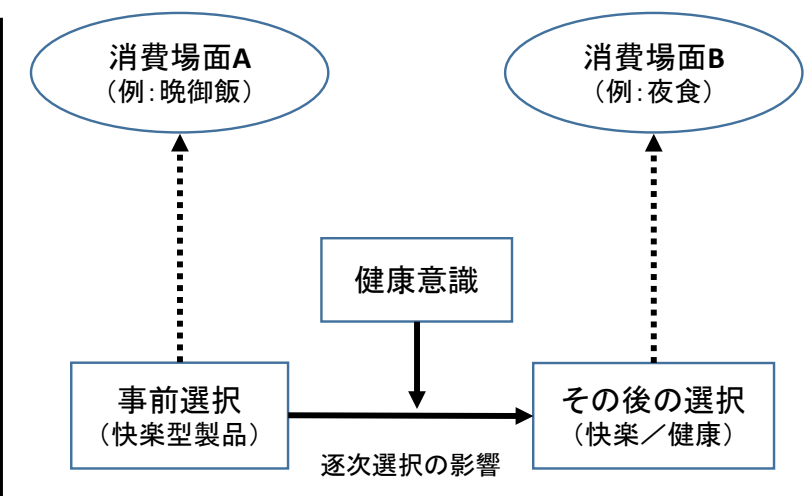

各選択の関連性(低):消費場面が異なる
えられる (Dhar \& Simonson, 1999)。しかしながら, H1 の設定の際にも議論した通り, 事前選択の結果によって, その後の選択の結果に差が生じるのは, 複数の目標間で コンフリクト状態にある消費者, つまり，本研究では健 康意識の高い消費者の場合のみであると考えられる。

即ち，健康意識が高い消費者が，事前選択として快楽 型製品を選択した場合，健康目標は進展がなされていな いため, その後の選択では健康型製品を選択する傾向が 推測できるが, ここで重要な点は, このような傾向は, 各選択の関連性が高い場合においてより顕著であると考 えられる点である。換言すると，健康意識が高い消費者 であっても，各選択の関連性が低い場合には，その後の 選択において，進展がなされていない目標に従う選択を 行う可能性はより低くなることが考えられる。即ち,

$\mathrm{H} 2$ 複数の目標間でコンフリクト状態にある場合, 各選 択の関連性が高い場合の方が，低い場合よりも，事 前選択の結果を考慮し，その後の選択では，進展が なされていないもう一方の目標に従う選択を行う

が設定できる。

一方，健康意識が低い消費者は，健康目標と快楽目標 の間でコンフリクト状態ではないため，事前選択におい て快楽型製品を選択することによって，健康目標が活性 化するわけではない。そのため，各選択の関連性に関わ
らず, その後の選択の結果に差は生じないと考えられる。

\section{IV. 実験}

\section{1. 実験 $1 ：$ 健康意識}

(1) 概要

ここでは, H1 の検証を行う。実験デザインは，2（事 前選択の結果：健康型製品／快楽型製品） $\times 2 （$ 健康意 識：高／低）で，各要因ともに参加者間計画である。実 験はインターネット上で行い, 参加者は 30 代から 50 代 の男女 223 名であった。そのうち, 分析対象として不適 切であると判断した参加者を除外した結果, 分析対象は 201 名となった ${ }^{1)}$

まず，全ての参加者に「晚御飯を一人で食べることに なり，近所の食品スーパーへ買物に出かけた」というシ ナリオが提示された。続いて, 参加者はランダムに二分 され，事前選択として健康型製品「豆腐カツ」，もしく は, 快楽型製品「トンカツ」のどちらか一方を選択した ことが記載された文章が与えられた。

次に, 全ての参加者に対して, その後の選択場面とし て「食後のデザートを選ぶために，アイス売場を訪れた」 というシナリオが与えられ，2つの選択肢が同時に提示 された。具体的には, 健康型製品「低糖質アイス」と快 楽型製品「プレミアムアイス」で，それぞれの成分とイ 
ラストが記載された文章が提示された ${ }^{2)}$ 。その後, 参加 者は，シナリオ場面でのアイス購買意図とアイスを選択 する際に重視する評価項目，そして，健康意識と操作確 認のための各選択肢評価（健康評価, 快楽評価）につい て回答するよう求められた。

購買意図は, Mukhopadhyay and Johar（2009, Study2, 3）を参考にし，直接比較によって測定した。具体的に は,「低糖質アイス：是非買いたい（1）」「低糖質アイ ス：買いたい（2)」「低糖質アイス：やや買いたい（3）」 「どちらとも言えない (4)」「プレミアムアイス : やや買 いたい（5)」「プレミアムアイス：買いたい（6)」「プレ ミアムアイス：是非買いたい（7）」の 7 段階で測定した。 アイス選択の際に重視する評価項目は,「今日の晚御飯 の食後のデザートを選択する際に，重視する評価項目に ついてお伺いします」とした上で，「健康面を重視する」 「カロリーや糖質を重視する」を設定した。また，健康意 識は, Chernev (2011), Lee et al.（2016）の体重管理に 対する意識の設問項目を参考にして,「私は，健康管理に 対して関心が高い」「私は, 健康状態を維持・向上させた いと考えている」「自分の健康管理は自分でしなければな らない」を設定した。これらの設問はすべて，「全く当て はまらない（1）」から「非常に当てはまる（7）」のリッ カート尺度で測定した。

\section{（2）分析結果と考察}

まずは，事前選択とその後の選択において提示した各 選択肢について, 操作確認を行った。各選択肢の健康と 快楽の評価項目を比較した結果，事前選択ではトンカツ を快楽型製品, 豆腐カツを健康型製品, そして, その後 の選択ではプレミアムアイスを快楽型製品, 低糖質アイ スを健康型製品として設定することは適切である点が確 認できた ${ }^{3)}$ 。また，健康意識については，上記した 3 項 目の合算平均值を算出し（クロンバック $\alpha=.85, M=4.63$, $S D=1.18)^{4)}$, 平均值の高低によって参加者を 2 群に分類 した（高, n: $110 /$ 低, n: 91)。

以下では, 仮説検証の結果について記述する。独立変 数として事前選択の結果（快楽型製品／健康型製品）と 健康意識 (高 $/$ 低), 従属変数としてその後の選択の購買 意図を設定し，二元配置分散分析を実施した。その結果， 主効果については, 事前選択の結果は $10 \%$ 水準で有意と なったが $\left(F(1,197)=3.22, p<.10,{ }_{\mathrm{p}} \eta^{2}=.02\right.$, Power=.56)， 健康意識は有意な結果が示されなかった $(F(1,197)=.98$, $p=.33)$ 。これらの交互作用は $5 \%$ 水準で有意に示された ため $\left(F(1,197)=4.02, p<.05,{ }_{\mathrm{p}} \eta^{2}=.02\right.$, Power $\left.=.52\right)$, 単純 主効果の検定を行った（図 2)。

健康意識が高い消費者の場合, 事前選択の結果によっ てその後の選択の購買意図に有意な差が示された（ $M_{\text {事 }}$ 前: 快楽 $=3.74, M_{\text {事前 : 健康 }}=4.73, F(1,197)=7.97, p<.01$,

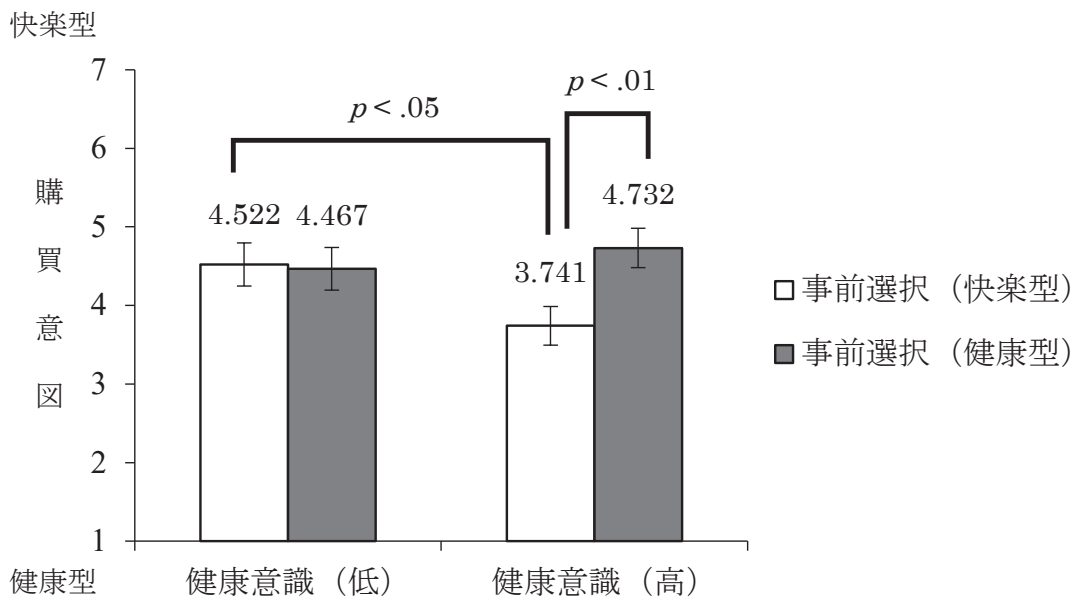


${ }_{\mathrm{p}} \eta^{2}=.07$, Power $\left.=.80\right)$ 。具体的には，事前選択において 健康型製品（快楽型製品）を選択した場合の方が，快楽 型製品（健康型製品）を選択した場合よりも，その後の 選択に打いて快楽型製品（健康型製品）への購買意図が 高い傾向が示された。このことから，H1 は支持された。 一方で，健康意識が低い消費者の場合は，事前選択の 結果によって, その後の選択の購買意図に有意な差が示 されなかった $\left(M_{\text {事前: 快楽 }}=4.52, M\right.$ 事前: 健康 $=4.47$, $F(1,197)=.02, p=.89)$ 。

続いて，事前選択において健康型製品を選択した場合 には，健康意識の高低によってその後の選択における購 買意図に差が見られなかった（ $M_{\text {健康意識 } \text { 低 }}=4.47, M_{\text {健 }}$ 康意識: 高 $=4.73, F(1,197)=.52, p=.47)$ 。この点は, 健康 意識が高い消費者の場合は，事前選択において健康目標 に従った選択を行うことで, 健康目標が進展したため, その後の選択では進展がなされていない快楽目標に対応 した選択肢に対して購買意図をより抱いた結果であると 理解できる。

また，事前選択が快楽型製品の場合には，健康意識が 高い消費者の方が低い消費者よりも，その後の選択に抢 いて健康型製品への購買意図が高い傾向が確認された $\left(M_{\text {健康意識 }: \text { 低 }}=4.52, M_{\text {健康意識 }: \text { 高 }}=3.74, F(1,197)=4.47\right.$, $p<.05, \mathrm{p}^{2}=.04$, Power $\left.=.81\right)$ 。このことは，健康意識の 高い消費者が，その後の選択では進展がなされていない 健康目標に従う選択を行ったためであると解釈でき，仮
説を支持する結果であると言える。

\section{（3）実験 1 の追加分析}

続いて，逐次選択の影響が生じる際の心理メカニズム について分析を行い，仮説検証の結果をより具体的に考 察する。

ここでは調整媒介分析を実施した。媒介変数には，(1) で記述した，その後の選択（アイス）の際に重視する評 価項目，「健康面を重視する」「カロリーや糖質を重視す る」の合算平均値を設定し (クロンバック $\alpha=.95, M=4.00$, $S D=1.52 ）$ ), その後の選択に打いて健康に関してどの程 度の意識が向けられているのかを捉えようとした。つま り，健康目標が活性化している場合には当該得点は高く なり，健康目標が活性化していない場合には低くなる。

独立変数は事前選択の結果（快楽型製品／健康型製 品), 従属変数はアイス購買意図, そして, 調整変数は健 康意識を設定した。

回帰分析の結果, 媒介变数に対する独立変数（事前選 択の結果）と調整変数（健康意識）の交互作用が確認さ れたため $(\beta=-.11, p<.1)$, 健康意識の高低に分けて分析 を行った ${ }^{6)}$ 。その際, 調整媒介分析においては, 調整変 数の $\pm 1 \mathrm{SD}$ で参加者を分類した上で分析することが一般 的であるため（Preacher, Rucker, \& Hayes, 2007)，本研究 でもそれを踏襲した（図 3）。

健康意識が高い消費者は, 事前選択で快楽型製品を選

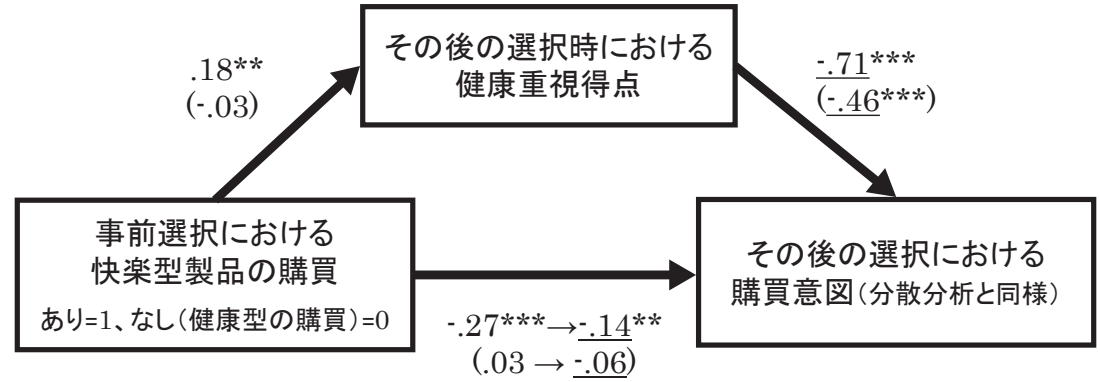

※数值は標準化係数であり, 上段は健康意識の高群, 下段（カッコ内）は低群の数值で ある。その内, 下線が引かれている数值は, 従属変数に対する独立変数と媒介变数の重 回帰分析の数值であり，それ以外は，単回帰分析の数值である。 ※***は $p<.01, * * は p<.05$ を表している。 
択した場合，その後の選択における快楽型製品への購買 意図は低くなる傾向（ $\beta=-.27, p<.01)$ ，そして，その後 の選択時に扔ける健康重視得点は高くなる傾向が示され た（ $\beta=.18, p<.05) 。$ ブートストラップ検定の結果（標本 数 $=2,000)$, 間接効果が認められたことから $(\mathrm{B}=-.46$, $\beta=-.13, p<.05,95 \%$ 下限 $=-.93,95 \%$ 上限 $=-.06)$, 事前選択の結果として快楽型製品（健康型製品）を選択 した場合には，その後の選択に打いて健康に関して意識 がより向けられ (向けられなくなり), その結果として, その後の選択では健康型製品（快楽型製品）への購買意 図がより高くなる傾向が示された。これは，H1 を裏付 ける結果である。

一方で, 健康意識が低い消費者は, 媒介変数や従属変 数に対する独立変数の直接効果はいずれも有意ではなく, ブートストラップ検定の結果（標本数 $=2,000 ） も$ ，間 接効果 $(\mathrm{B}=.06, \beta=.01, p=.73)$ は有意ではなかった。こ のことから, 事前選択の結果によってその後の選択時に おいて健康面を意識する程度に差が生じないことから， 健康意識が低い消費者の場合には，健康目標と快楽目標 の間でコンフリクトが生じていないことが示唆できる。

\section{2. 実験 2 : 各選択の関連性}

\section{(1) 概要}

実験 2 では, H2 の検証を行う。実験デザインは, 2 （各選択の関連性：高／低） $\times 2$ (健康意識：高／低）で, 各要因ともに参加者間計画である。実験はインターネッ 卜上で行い，参加者は 30 代から 50 代の男女 221 名であ る。そのうち, 分析対象として不適切であると判断した 参加者を除外した結果，分析対象は 190 名となった。

参加者には，実験 1 と同様に「晚御飯を一人で食べる ことになり，近所の食品スーパーへ買物に出かけた」と いうシナリオが提示された。その後, 事前選択として快 楽型製品「トンカッ」を選択したシナリオが全ての参加 者に与えられた。

続いて, その後の選択（アイス）のシナリオが与えら れた。ここでは, 事前選択とその後の選択の関連性を操 作することを目的として，その後の選択の消費場面が, 事前選択と同じ場合（今日の晚御飯の食後のデザート） と異なる場合（明日の昼食の食後のデザート）を用意し，
参加者にはどちらか一方のシナリオが提示された。各選 択の消費場面が同じ場合は各選択の関連性は高く, 異な る場合は関連性は低くなることを想定している。

従属変数には，その後の選択の購買意眓を設定した。 選択肢として健康型製品「低糖質アイス」と快楽型製品 「プレミアムアイス」の両方を提示し, 実験 1 と同様に 直接比較によって測定した。

これに加え, その後の選択の際に考慮した点について, 設問項目「晚御飯の献立を意識して選択した」「カロリー や糖質について晚御飯の献立とのバランスを考慮した」 に回答してもらった。また, 健康意識については実験 1 と同じ設問, そして, 各選択肢の操作確認に用いる設問 を設定し，すべて 7段階のリッカート尺度で測定した。

\section{(2) 分析結果と考察}

まずは，その後の選択において提示した各選択肢につ いて操作確認を行った。各選択肢の健康と快楽の評価項 目を比較した結果, プレミアムアイスを快楽型製品, 低 糖質アイスを健康型製品として設定することは適切であ る点が確認できた7)。

各選択の関連性に関しては, その後の選択の際に考慮 した点の設問項目「晚御飯の献立を意識して選択した」 について, 消費場面の同異で比較した。その結果, 消費 場面が同じ場合の方が, 異なる場合よりも, その後の選 択を行う際に晚御飯の献立をより意識していることが示 されたため $\left(M_{\text {消費場面 : 同 }}=3.97, M_{\text {消費場面 }}\right.$ 異 $=3.15$, $t(188)=-3.50, p<.001, d=.51, \quad$ Power $=.93)$, 関連性の 操作も問題なく行われたと判断した。最後に, 健康意識 については, 実験 1 と同様に, 3 項目の合算平均値を算 出し (クロンバック $\alpha=.80, M=4.57, S D=.91){ }^{8)}$, 平均值 の高低によって参加者を 2 群に分類した（高, n: $96 /$ 低, n: 94)。

各選択の関連性（高／低）と健康意識（高／低）を独 立変数, その後の選択の購買意図を従属変数とした二元 配置分散分析の結果, 主効果について各選択の関連性は 有意な差が示されたが $\left(F(1,186)=14.85, p<.001,{ }_{\mathrm{p}} \eta^{2}=.07\right.$, Power $=.97)$, 健康意識は有意な差は示されなかった $(F(1,186)=.96, p=.42)$ 。これらの交互作用が $5 \%$ 水準で 有意に示されたため $\left(F(1,186)=4.61, p<.05,{ }_{\mathrm{p}} \eta^{2}=.02\right.$, 


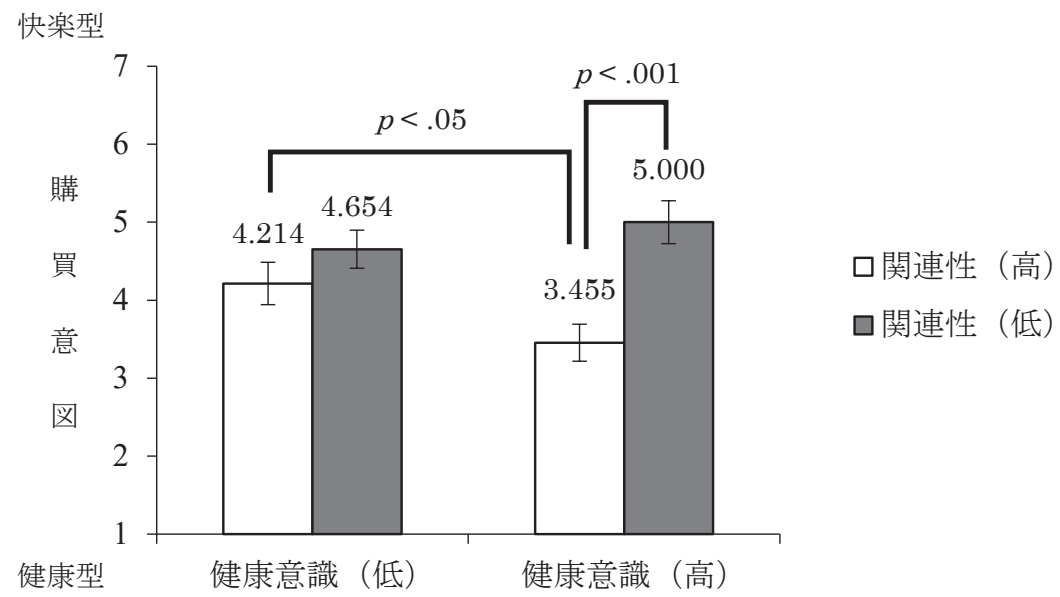

Power $=.58$ ），単純主効果の検定を行った（図 4)。

健康意識が高い消費者の場合，関連性の高低によって その後の選択の購買意図に有意な差が示された（ $M_{\text {関連 }}$ 性 : 高 $=3.46, M$ 関連性 : 低 $=5.00, F(1,186)=18.10, p<$. $001, \mathrm{p} \eta^{2}=.16, \quad$ Power $\left.=.99\right)$ 。具体的には, 関連性が高い 場合の方が，低い場合よりも，その後の選択において健 康型製品への購買意図が高い傾向が確認された。このこ とは, 健康目標と快楽目標の間でコンフリクト状態にあ る場合, その後の選択において進展がなされていない目 標（実験 2 では健康目標）に従う選択を行う傾向は，各 選択の関連性が高い場合の方が低い場合よりも顕著であ ることを示している。このことから，H2 は支持された。

一方，健康意識が低い消費者の場合は，関連性の程 度によってその後の選択の購買意図に有意な差が示さ

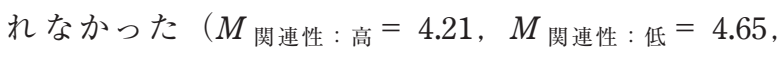
$F(1,186)=1.45, p=.23)$ 。

各選択の関連性が高い場合，健康意識が高い消費者の 方が，低い消費者よりもその後の選択において健康型製

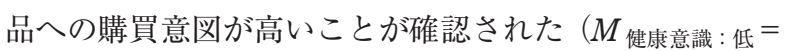
$4.21, M_{\text {健康意識: 高 }}=3.46, F(1,186)=4.44, p<.05,{ }_{\mathrm{p}} \eta^{2}=.05$, Power =.51)。一方で，関連性が低い場合には，健康意識

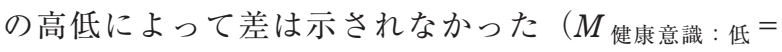
$\left.4.65, M_{\text {健康意識 }: \text { 高 }}=5.00, F(1,186)=.89, p=.35\right)$ 。この ことから，健康意識が高い消費者であっても，各選択の
関連性が低い場合には，健康意識が低い消費者と同様に， 事前選択の結果をあまり考慮することなくその後の選択 を行う傾向が指摘でき，H2 を支持する結果であると言 える。

\section{（3）実験 2 の追加分析}

実験 1 と同様に, 逐次選択の影響が生じるメカニズム について調整媒介分析を行う。但し，実験 2 では, 事前 選択の結果は快楽型製品のみを設定しているため, 独立 変数に事前選択の結果を設定することはできなかった。

媒介変数には, その後の選択の際に考慮した点に関す る設問項目「カロリーや糖質について晚御飯の献立との バランスを考慮した」を設定し, 選択時において健康に どの程度の意識が向けられているのかを捉えようとした。 独立変数には各選択の関連性, 従属変数にはその後の選 択の購買意図, そして, 調整変数には健康意識を設定 した。

回帰分析の結果, 独立変数（各選択の関連性）と調整 変数（健康意識）の交互作用が媒介变数に及ぼす影響 $(\beta=-.16, p<.05)$ が有意であったため, 実験 1 と同様に 健康意識の高低（土1SD）で参加者を分類し分析を行っ た（図 5）9。

健康意識が高い消費者は, 事前選択で快楽型製品を選 択した場合，各選択の関連性が低ければ，その後の選択 


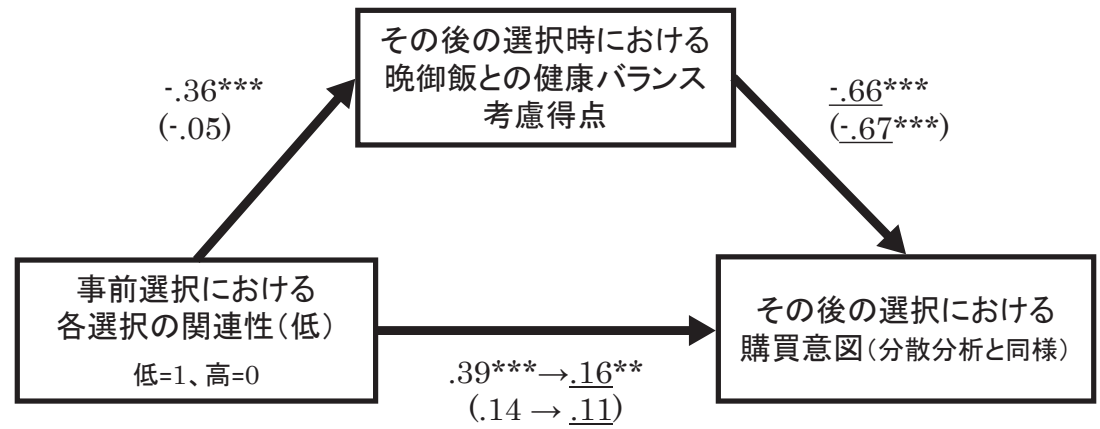

※実験 2 では事前選択として快楽型製品の選択を想定している。

※数值は標準化係数であり, 上段は健康意識の高群, 下段（カッコ内）は低群の数值で ある。その内, 下線が引かれている数值は, 従属変数に対する独立変数と媒介变数の重 回帰分析の数值であり，それ以外は，単回帰分析の数值である。 ※***は $p<.01, * *$ は $p<.05$ を表している。

における快楽型製品への購買意図は高くなる傾向 $(\beta=.39$, $p<.01)$ ，そして，その後の選択時における健康バランス 考慮得点は低くなる傾向が示された $(\beta=-.36, p<.01)$ 。 ブートストラップ検定の結果（標本数 $=2,000 ）$, 間接効 果が認められ $(\mathrm{B}=.87, \beta=.24, p<.001,95 \%$ 下限=.39, $95 \%$ 上限 $=1.43)$, 各選択の関連性の高低から購買意図 への直接効果は減衰していることが示された。このこと から，事前選択として快楽型製品を選択した場合には， 各選択の関連性が高い（低い）場合，その後の選択にお いて健康面のバランスに関する情報処理が促進（抑制） され，その結果として，その後の選択における健康型製 品 (快楽型製品) への購買意図がより高くなる傾向が確 認できた。

つまり，健康意識が高い消費者であっても，事前選択 において快楽目標が進展した場合に，その後の選択にお いてコンフリクト目標である健康目標に従い情報処理や 選択を行うのは, 各選択の関連性が高い場合に限られる 点が指摘でき， H2 を支持する結果であると言える。

一方, 健康意識が低い消費者は, 媒介変数や従属変数 に対する独立変数の直接効果は有意ではなかった。また, ブートストラップ検定の結果（標本数 $=2,000 ）$ 間接効 果 $(\mathrm{B}=.12, \beta=.03, p=.64)$ も有意ではなかった。

\section{V. 結論}

\section{1. 本研究の成果}

本研究では, 逐次選択の影響の調整要因として, 各選 択の関連性と消費者の健康意識に着目して検討してきた。 実験 1 では, 既存研究で示されている逐次選択の影響 が, 健康意識によって調整される点を明らかにした。具 体的には, 健康意識が高い消費者の場合には, 事前選択 とその後の選択においてコンフリクトする目標間でバラ ンス傾向を示唆する選択の傾向を確認した。

実験 2 では, 逐次選択は複数の選択間における選択行 動であるにも関わらず, 調整要因として各選択の関係 （Dhar \& Simonson, 1999）に着目した議論が不十分であ ることから, 事前選択とその後の選択の関連性に着目し た上で，この関連性と健康意識の交互作用によって逐次 選択の影響が調整される点を明らかにした。具体的には， 健康意識が高い消費者の場合, 各選択の関連性が高い場 合の方が，低い場合よりも，コンフリクトする目標間で バランス傾向を示唆する選択の傾向を確認した。これら の知見は，逐次選択の影響が生じる新たな条件を特定す るものであり学術的貢献として提示できる。

実務的貢献としては, 消費者の逐次選択の影響を考慮 すると, 店舗（テナント）ごと，製品カテゴリー（棚） 
ごとにマーケティングを策定・実行するだけでは十分で はないことが明らかになった点である。企業側は，ター ゲットとする消費者が，どのような目標間でコンフリク 卜状態にあるのかを分析した上で，各目標にバランスよ く対応するような，店舗の配置，製品カテゴリーの提示 について検討することが重要であろう。

\section{2. 本研究の限界と課題}

本研究の限界は, 逐次選択場面として事前選択とその 後の選択の計 2 つの選択のみに言及している点である。 この点は, 逐次選択研究に打ける課題として Sunaga （2013）でも指摘されている。また，逐次「選択」につ いて議論してきたが，今回の実験では，購買意図の測定 にとどまっており，この点も限界の一つである。これら に加え, 本研究では, 事前選択がその後の選択に及ぼす 影響として逐次選択の影響について議論してきたが，そ の逆の影響，つまり，将来の選択が現在の選択に及ぼす 影響（Fishbach \& Dhar, 2005）も考えるべきである。さ らに，媒介分析の際に設定した媒介変数（その後の選択 時に打ける心理）をより正確に捉えるためには，事前選 択前とその後の選択時の 2 時点で消費者の意識を測定 し，その変化を設定するべきである。

今後の課題は, 目標の内容に関するより詳細な分析で ある。自己制御に関する目標の内容によって, 調整要因 の内容や影響程度が異なる可能性があり，この点につい て十分な議論が必要である。また，その際には，各選択 の関連性についてもより精緻な議論が必要である。本研 究では, 消費場面の同異によって関連性の高低を判断し たが，その他にも関連性に影響を及ぼす要因は存在する であろうし，その議論を通じて関連性概念自体を再吟味 する必要もあるだろう。

\section{謝辞}

このような貴重な機会を賜り，石淵順也教授（関西学 院大学）には深く感謝申し上げたい。尚，本稿は科学研 究費 (19K13835) の助成を受けた研究成果の一部である。

注

1）操作確認に関する設問の後に設定した，設問「普段から，
低カロリー・低糖質の商品だけを買っている」に対して, 「非常にあてはまる」「あてはまる」「やや当てはまる」と回 答した者（n: 19）は, 逐次選択の影響について議論する余 地がないと判断し分析から除外した。その他, 矛盾回答が ある者も除外した。実験 2 では, 上記設問に加えて, 「普段 から, 高カロリー・高糖質の商品だけを買っている」につ いても回答を求めており, これに該当する参加者も分析か ら除外している（n: 8)。本来ならば，実験 1 においても実 験 2 と同様に健康型商品, 快楽型商品のどちらについても 極端に偏った参加者を除外するべきであったが，この点は， 実験 1 の限界である。尚, 実験 2 では, 設問「普段から, 低カロリー・低糖質の商品だけを買っている」の該当者（n: 16），そして，矛盾回答がある者を除外している。

2）説明文としては，容量を $120 \mathrm{~g}$ に統一した上で，実際に販 売されている各商品の数値を基にカロリー值と糖質值を算 出し, 提示した。具体的には, 低糖質アイス $(80 \mathrm{kcal}$, 糖 質 $7.6 \mathrm{~g})$ ，プレミアムアイス $(266 \mathrm{kcal}$, 糖質 $20 \mathrm{~g})$ であ る。イラストはシルエットで表現されたもので，それぞれ 同じものを提示した。

3）事前選択での各選択肢については, 「健康そうだ」( $M$ 事前： 快楽 $=3.22, M$ 事前: 健康 $=4.84, t(199)=-8.76, p<.001)$, 「カロリーや糖質が低そうだ」 $(M$ 事前 : 快楽 $=2.50, M$ 事 前：健康 $=4.57, t(199)=-11.36, p<.001)$, 「美味しそう だ」 $(M$ 事前 : 快楽 $=5.20, M$ 事前 : 健康 $=4.13$, $t(199)=4.95, p<.001)$ が示された。その後の選択における 選択肢では，対応のある $\mathrm{t}$ 検定を実施し，「健康そうだ」 $(M$ プレミアム $=3.48, M$ 低糖質 $=4.46, t(200)=-7.91$ $p<.001)$ ，「カロリーや糖質が高そうだ」（Mプレミアム $=$ $5.13, M$ 低糖質 $=3.18, t(200)=15.46, p<.001)$ ，「美味し そうだ」（ $M$ プレミアム $=5.51, M$ 低糖質 $=3.54$, $t(200)=15.29, p<.001)$ が示された。

4） Hair, Black, Babin, and Anderson（2010）を参考にすると, 合算平均值と各測定変数の相関係数は, いずれの值も基準 .6以上を満たしていた。また，クロンバック $\alpha$ 係数につい ても基準.7 以上を満たしていた。これらのことから，測定 尺度の妥当性は確認できた。

5）合算平均值と各測定変数の相関係数はいずれの值も基準. 6 以上を満たしていた。また，合算平均值のクロンバック $\alpha$ 係数についても基準. 7 以上を満たしていた。

6）調整変数のその他の影響は以下である。従属変数に対する 独立変数との交互作用項 $(\beta=-.13, p<.05)$, 媒介変数との 交互作用項 $(\beta=-.12, p<.05)$ 。

7）対応のある $\mathrm{t}$ 検定を実施し，「健康そうだ」（ $M_{\text {プレミアム }}=$ $\left.3.61, M_{\text {低糖質 }}=4.55, t(189)=9.13, p<.001\right) ， 「$ 「ロリーや 糖質が高そうだ」（ $M$ プレミアム $=5.14 ， M_{\text {低糖質 }}=3.13$, $t(189)=15.71, p<.001)$, 「美味しそうだ」 $(M$ プレミアム $=$ $5.53, M_{\text {低糖孟 }}=3.63, t(189)=15.25, p<.001 ）$ が示された。

8）合算平均值と各測変数の相関係数はいずれの值も基準. 6 以 上を満たしていた。また，合算平均值のクロンバック $\alpha$ 係 数は.80であり, 基準.7 以上を満たしていた。これらのこと から, 実験 1 と同様に, 測定尺度の妥当性は確認できた。

9）調整変数のその他の影響は以下である。従属変数に対する 独立変数との交互作用項 $(\beta=-.03, p=.65)$, 媒介変数との 交互作用項 $(\beta=.01, p=.88)$ 。 


\section{References}

Akamatsu, N., \& Fukuda, R. (2018). The influence of shopping goals on consumers' sequential choices. Asia-Pacific Advances in Consumer Research, 12, 4-7.

Chandon, P., \& Wansink, B. (2007). The biasing health halos of fastfood restaurant health claims: Lower calorie estimates and higher side-dish consumption intention. Journal of Consumer Research, 34(3), 301-314.

Chernev, A. (2011). The dieter's paradox. Journal of Consumer Psychology, 21(2), 178-183.

Dhar, R., \& Simonson, I. (1999). Making complementary choices in consumption episodes: Highlighting versus balancing. Journal of Marketing Research, 36(1), 29-44.

Dholakia, U. M., Gopinath, M., \& Bagozzi, R. P. (2005). The role of desires in sequential impulsive choices. Organizational Behavior and Human Decision Process, 98(2), 179-194.

Finkelstein, S. R., \& Fishbach, A. (2013). When healthy food makes you hungry. Journal of Consumer Research, 37(3), 357-367.

Fishbach, A., \& Dhar, R. (2005). Goals as excuses or guides: The liberating effect of perceived goal progress on choice. Journal of Consumer Research, 32(3), 370-377.

Fishbach, A., Dhar, R., \& Zhang, Y. (2006). Subgoals as substitutes or complements: The role of goal accessibility. Journal of Personality and Social Psychology, 91(2), 232-242.

Hair, J. F., Black, W. C., Babin, B. J., \& Anderson, R. E. (2010). Multivariate data analysis. Upper Saddle River, NJ: Pearson Education.

Huber, J., Goldsmith, K., \& Mogilner, C. (2008). Reinforcement versus balance response in sequential choice. Marketing Letter, 19(3-4), 229-239.

Laran, J. (2010a). Choosing your future: Temporal distance and the balance between self-control and indulgence. Journal of Consumer Research, 36(6), 1002-1015.

Laran, J. (2010b). Goal management in sequential choice: Consumer choice for others are more indulgent than personal choices. Journal of Consumer Research, 37(2), 304-314.

Laran, J., \& Janiszewski, C. (2009). Behavioral consistency and inconsistency in the resolution of goal conflict. Journal of Consumer Research, 35(6), 967-984.

Lee, Y. K., Weaver, K., \& Garcia, S. M. (2016). I'll have fries with that: Increasing choice complexity promotes indulgent food choices. Psychology \& Marketing, 33(7), 505-515.

May, F., \& Irmak, C. (2014). Licensing indulgence in the present by distorting memories of past behavior. Journal of Consumer Research, 41(3), 624-641.

Moorman, C., \& Matulich, E. (1993). A model of consumers' preventive health behaviors: The role of health motivation and health ability. Journal of Consumer Research, 20(2), 208-228.

Mukhopadhyay, A., \& Johar, G. V. (2009). Indulgence as self-reward for prior shopping restraint: A justification-based mechanism. Journal of Consumer Psychology, 19(3), 334-345.

Mukhopadhyay, A., Sengupta, J., \& Ramanathan, S. (2008). Recalling past temptations: An information-processing perspective on the dynamics of self-control. Journal of
Consumer Research, 35(4), 586-599.

Okada, E. M. (2005). Justification effects on consumer choice of hedonic and utilitarian goods. Journal of Marketing Research, 42(1), 43-53.

Preacher, K. J., Rucker, D. D., \& Hayes, A. F. (2007). Addressing moderated mediation hypotheses: Theory, methods, and prescriptions. Multivariate Behavioral Research, 42(1), 185227.

Ratneshwar, S., Pechmann, C., \& Shocker, A. D. (1996). Goalderived categories and the antecedents of across-category consideration. Journal of Consumer Research, 23(3), 240-250.

Srivastava, R. K., Alpert, M. I., \& Shocker, A. D. (1984). A customer-oriented approach for determining market structures. Journal of Marketing, 48(2), 32-45.

Sunaga, T. (2013). Interdependence among choice behaviors: Background contrast effect and sequential choices. Journal of Business Administration of Kwansei Gakuin University, 61(2), 71-84. (須永努（2013）。「消費者の選択行動間における相 互依存効果：背景対比効果と逐次選択」『商学論究』61(2), 71-84) (In Japanese)

\section{赤松 直樹（あかまつなおき）}

明治学院大学経済学部准教授

2015 年慶應義塾大学大学院商学研究科博士後期課程単位 取得退学。同年千葉商科大学政策情報学部助教, 2018 年明 治学院大学経済学部専任講師。2020 年より現職。博士（商 学)

\section{福田 怜生（ふくだ れお）}

亜細亜大学経営学部専任講師

2016 年学習院大学大学院経営学研究科博士後期課程単位 取得退学。同年学習院大学経済経営研究所客員所員。2018 年より現職。 